\title{
ECONOMICS
}

\section{RE-EXAMINATION OF THE SURPLUS AGRICULTURAL LABOUR IN CHINA}

\author{
by \\ Fung Kwan \\ Department of Economics \\ University of Macau
}

\author{
and
}

Yanrui Wu

Business School

University of Western Australia

and

Shuaihe Zhuo

Department of Economics

University of Macau

DISCUSSION PAPER 12.25 


\title{
RE-EXAMINATION OF THE SURPLUS AGRICULTURAL LABOUR IN CHINA
}

\author{
by \\ Fung Kwan \\ Department of Economics, University of Macau, Macao \\ and \\ Yanrui Wu \\ Economics, Business School, University of Western Australia, Australia \\ and \\ Shuaihe Zhuo \\ Department of Economics, University of Macau, Macao
}

DISCUSSION PAPER 12.25

Abstract This paper contributes to the pool of studies of rural underemployment in China. It is devoted to the conceptualization and measurement of surplus labour. The agricultural labour requirement function is estimated by the stochastic frontier analysis (SFA) with China's prefecture-level data. Surplus labour or inefficient labour is obtained by subtracting the required labour from the actual labour participated in agriculture. Our analysis indicates that the existing size of agricultural surplus labour in rural China is still significantly large with the continued practice of the household registration system and China's WTO membership. However, the size has been decreasing over the last decade. We thus conclude that China is probably experiencing the second stage of the Lewis-Fei-Ranis dualistic economic framework.

Keywords: surplus labour, Chinese agricultural labour, stochastic frontier JEL Classification: J64, O53, R23 


\section{Introduction}

Economists are fiercely debating whether China has reached the Lewis turning point where the marginal product of labour matches the paid wage. For example, Ba (2011) argued that China has already passed the Lewis turning point while Cai (2007) claimed that the rural surplus labourers below 40 amounted to 58 million or 11.7 percent at most. Yet, an important qualification for such argument is the existence of redundant labour in China's countryside. In fact, rural labour force has been decreasing from around 490 million in the mid-1990s to less than 470 million in the end of 2000s. Of these, 259 million were working in agriculture in 2009, 13 percent less than the figure in 1980 (Table 1).

This study attempts to quantify the extent of surplus agricultural labour in rural China, if any, by the stochastic frontier analysis (SFA). We employ the prefecture level data to estimate the surplus labour. In the existing studies using the provincial data, rural households in different prefectures are pooled into one single decision making unit (DMU). Using prefecture level data allows us to treat the household behaviour homogenous in the countryside of a prefecture but heterogeneous across prefectures. Each prefecture-level city acts as a competitive DMU in our study.

The remaining parts of this article are organized as follows. Section 2 presents a brief review of the literature of surplus labour measurement in rural China. Section 3 outlines the analytical framework of stochastic frontier measurement of surplus labour. Section 4 shows the methodology and empirical specification. Section 5 describes the dataset. Section 6 presents the estimated labour-use frontier and the

estimated surplus labour. Section 7 examines the relationship between surplus labour and the dual economic framework of China. Section 8 concludes the paper. 
Table 1: Rural Labour in China: Size and Growth (1980 - 2009, Selected Years)

\begin{tabular}{lcccccccr}
\hline Year & Rural L & RE L & PE L & Ag L & Rural L & RE L & PE L & Ag L \\
\hline$(1)$ & $(2)$ & $(3)$ & $(4)$ & $(5)$ & $(6)$ & $(7)$ & $(8)$ & $(9)$ \\
\hline 1980 & 318.4 & 30.0 & 0.0 & 298.1 & $* *$ & $* *$ & $* *$ & $* *$ \\
1985 & 370.7 & 69.8 & 0.0 & 303.5 & $* *$ & $* *$ & $* *$ & $* *$ \\
1990 & 477.1 & 92.7 & 16.0 & 368.4 & $* *$ & $* *$ & $* *$ & $* *$ \\
1995 & 490.3 & 128.6 & 35.3 & 326.4 & 0.6 & 7.7 & 24.1 & -2.3 \\
2000 & 489.3 & 128.2 & 40.7 & 320.4 & 0.0 & -0.1 & 3.1 & -0.4 \\
2005 & 484.9 & 142.7 & 44.9 & 297.3 & -0.2 & 2.3 & 2.1 & -1.4 \\
2009 & 468.7 & 155.8 & 54.0 & 258.9 & -0.8 & 2.3 & 5.1 & -3.2 \\
\hline $1990-2009$ & & & & & -0.1 & 2.6 & 8.5 & -1.5 \\
\hline
\end{tabular}

Notes: Rural L: total labour force in rural area; RE L: labour employed by the rural enterprises; PE L: labour participated in private enterprises; AgL: agricultural labour force. Columns (2)-(5) are in million labourers, and (6)-(9) are average growth rates. **: data not available.

Sources: NBS (2010), pp. 118-9.

\section{Brief Literature Review}

A considerable amount of research has been devoted to the measurement of surplus labour in China. Minami \& Ma (2010) derived the equilibrium labour force by assuming that the marginal product of labour is equal to the subsistence wage in agriculture, and calculated the surplus labour. Accordingly, their estimated surplus was around 290 million for the period of 2001 - 2005. Unfortunately, total rural labour force was used to derive the surplus, and therefore such a huge figure is hardly convincing. Knight et al (2011) probably represents the latest contribution and they employed household survey data to derive the inefficient labour in rural China.

One of the significant advances in the field is the technical efficiency specification. Bhattacharyya \& Parker (1999) and Guo (2007) applied this approach and found the agricultural surplus labour was around $100 \sim 130$ million in the 1990s and the early 2000s. Kwan (2009) specified a stochastic cost frontier framework which was originally proposed by Battese \& Coelli (1995). With provincial dummy variables in the inefficiency term which is similar to the fixed effect model developed 
by Greene (2004, 2005), Kwan (2009) found that the amount of surplus labour was 138 million on average between 1980 and 2007.

Our paper contributes to the pool of study of surplus labour in rural China with several new insights. First, we adopt the approach of efficiency analysis with environmental variables to estimate the amount of surplus labour in China. Second, prefecture-level data are believed to be more suitable for the requirement of stochastic frontier analysis than the national- or provincial-level data. Third, our results provide further evidence of the existence of sizable inefficient labour in rural China, which may help understand a number of issues of the Chinese labour market, including the migrant workers, institutional constraints of labour transfer, and the debate of the Lewis turning point.

\section{Analytical Framework}

Labour is considered as one of the factor inputs in producing different outputs. The conventional production function implicitly imposes a neoclassical assumption of all DMUs operating at technical efficient level. Experiences of many developing economies show that agricultural production is possibly working below full capacity. To allow for potential inefficiency, which is unobservable and might be either varying or invariant over time but could be estimated empirically, a composite error term is included into the production function to capture technical inefficiency.

Intuitively, deviations from a production frontier may be regarded as the under-produced output due to inefficient factor-input utilization. This outputoriented measure of technical efficiency could be alternatively translated in an inputoriented measure by asking how much input quantities could be reduced without changing the output quantities. Particularly under the production technology facing 
constant returns to scale, ${ }^{1}$ both input-oriented and output-oriented frontier analyses are expected to yield the same results.

This paper adopts an input-oriented measurement of technical efficiency by specifying a stochastic cost frontier. To estimate a typical cost function, both input prices and input quantities are needed. In the absence of input price data which is popular in developing economies, we consider our labour input-requirement function with only outputs and quasi-fixed inputs, as argued by Battese et al. (2000, pp. $624,626 \& 629)$. The general form of labour-use function is:

$L=A \Pi_{j}^{n} Y^{j}$

where the $Y^{j} \mathrm{~s}$ are output variables determining the labour requirement or the minimum labour for producing output, at a given level of technology $A$.

The labour-use model has its origin of applying production frontiers (the inefficiency effect is subtracted from production) initially proposed by Diewert (1974) and Aigner et al. (1977), and extended by Kumbhakar \& Hjalmarsson (1995). Our paper is largely based on the modification of the stochastic frontier model developed by Battese \& Coelli (1995) with the following Cobb-Douglas specification:

$L=f\left(Y^{j}, X^{q}\right) e^{v+u}$

where $f($.$) is a labour requirement function, Y^{j} \mathrm{~S}$ are the outputs produced, $X^{q} \mathrm{~S}$ are the non-labour inputs which are treated as quasi-fixed, $v$ is the two sided error term and $u$ is the non-negative random term in association with the technical inefficiency. Labour requirement is, then, determined by five factors, namely, (1) outputs $Y^{j} ;(2)$

1 These two measures can also be applied to either increasing- or decreasing- return-to-scale technology with further expression. See Coelli et al. (2005), pp 52-57. 
any non-labour factor inputs at a given output level; (3) pre-conditioned production technology; (4) level of technical inefficiency and (5) a random term to capture factors such as weather and other uncontrollable elements.

If labour is fully efficient during production, i.e., the technical inefficiency $u$ is zero, then the labour requirement function $L^{*}$ is written as

$L^{*}=f\left(Y^{j}, X^{q}\right) e^{v}$

where $L^{*}$ denotes the optimal labour for production. The inefficient labour or surplus labour, $L^{S}$, is defined as the difference between observed labour input and optimal labour input:

$L^{S}=L-L^{*}$

Therefore, the ratio of surplus labour is

$\frac{L-L^{*}}{L}=1-\frac{f\left(Y^{j}, X^{q}\right) e^{v}}{f\left(Y^{j}, X^{q}\right) e^{v+u}}=1-e^{-u}$

Finally the amount of surplus labour is calculated as

$L^{S}=L\left(1-e^{-u}\right)$

\section{Empirical Model}

The agricultural labour requirement function of equation (2) in panel data form is specified as 
$\ln \mathrm{L}_{\mathrm{it}}=\alpha_{0}+\alpha_{1} \ln \mathrm{Y}_{\mathrm{it}}^{\mathrm{a}}+\alpha_{2} \ln \mathrm{Y}_{\mathrm{it}}^{\mathrm{b}}+\alpha_{3} \ln \mathrm{N}_{\mathrm{it}}+\alpha_{4} \ln \mathrm{M}_{\mathrm{it}}+\alpha_{5} \ln \mathrm{F}_{\mathrm{it}}+\alpha_{6} \mathrm{t}+\alpha_{7} t^{2}+\mathrm{v}_{\mathrm{it}}+\mathrm{u}_{\mathrm{it}}$ (7)

where $Y^{a}$ is the farming output, $Y^{b}$ is the non-farming agricultural output, $N$ is land, $M$ is the power of machineries, $F$ is the chemical fertilizer and $t$ is the time trend which is used to capture the effect of technological progress on labour requirement. The subscript $i$ denotes the prefecture-level cross section and subscript $t$ denotes the year.

We model the $u_{i t}$ by introducing a time-varying function to capture the inefficiency of labour use:

$\mathrm{u}_{\mathrm{it}}=z_{i t} \lambda+\varepsilon_{i t}$

where $z_{i t}$ represents a group of prefecture-specific environmental variables that could vary over time to affect inefficiency. Specifically,

$u_{i t}=\beta_{0}+\beta_{1} \operatorname{Ind}_{i t}+\beta_{2} U r b_{i t}+\beta_{3}\left(\ln M_{i t} / \ln N_{i t}\right)+\beta_{4}\left(Y_{i t}^{a} / Y_{i t}\right)+\beta_{5} t+\beta_{6} t^{2}+\Sigma \theta_{i} D_{i}+\varepsilon_{i t}$

where the Ind variable measures the level of industrialization (ratio of industrial output to the total output or GDP), the Urb variable measures the level of urbanization (ratio of the urban population to the total population), $\ln \mathrm{M} / \ln \mathrm{N}$ measures the level of mechanization (machinery power per unit of land), and $Y^{\mathrm{a}} / \mathrm{Y}$ measures relative weight of farming (the ratio of farming output over the total agricultural output). The $\mathrm{D}_{\mathrm{i}} \mathrm{s}$ intend to capture possible regional or provincial heterogeneities. 
The signs of $\beta_{1}, \beta_{2}, \beta_{3}, \beta_{4}, \beta_{5}$, and $\beta_{6}$ could be greater or smaller than zero, depending on a number of behaviour assumptions between the labour inefficiency and those exogenous variables. For instance, a higher level of industrialization implies that more industrial output is produced; indirectly workers for industrial production are expected to increase. It is hence possible for firms to employ more workers to cope with the production scale. Since some workers are expected to be migrants from the countryside permanently or temporarily, the amount of surplus labour is thus expected to become smaller.

A greater share of urban population could be originated from larger rural to urban labour migration, either permanently or temporarily, rather than the natural population growth in cities. Once migrants moved to the cities, demand for food is expected to increase. Therefore more agricultural labour may be required to meet the increase of food demand. In addition, labour migration also means a reduction in rural labour. Therefore, one will foresee a lower level of surplus agricultural labour.

The pace of mechanization is expected to be positively related to the labour inefficiency due to the substitution effect between labour and machines. That is, more machines per unit of land means relatively less labour required for farming and therefore more redundant labour in the countryside.

Furthermore, more farming output relative to total agricultural output should require more agricultural labour and therefore imply low inefficiency or a small pool of surplus labour, on the one hand. One the other hand, a higher farming output share could indicate a lower level of economic development and thus relatively lower labour productivity. The latter implies potentially more surplus labour.

For the purpose of empirical estimation, the following standard distributional assumptions on the components of the error term are made: 
$v_{i t} \sim \operatorname{iid} N\left(0, \sigma_{v}^{2}\right)$

$u_{i t} \sim \operatorname{iid} N^{+}\left(z_{i t} \lambda, \sigma_{u}^{2}\right)$

$\varepsilon_{i t} \sim \operatorname{iid} N\left(0, \sigma_{u}^{2}\right), \varepsilon_{i t} \geq-z_{i t} \lambda$

Equation (10) means that the two sided normal error term is independently and identically distributed and follows normal distribution with mean zero and variance $\sigma_{v}^{2}$. Equation (11) means that the level of technical inefficiency is independently and identically distributed and follows normal distribution truncated above zero with mean $z \lambda$ and variance $\sigma_{u}^{2} . z$ and $\lambda$ are defined in equations (8) and (9). With the above three specifications regarding the error terms, the labour requirement function can be estimated by the maximum likelihood method using Frontier $4.1{ }^{2}$

\section{Prefecture - Level Agricultural Data in China}

\section{Administrative Classifications}

Administrative areas in China are organized into three levels, provincial, prefecture and county, respectively. At the provincial level, its equivalent units include provinces, autonomous regions, municipalities under the central government, and the special administrative regions. Prefectures, on the other hand, include autonomous prefectures, counties, and autonomous counties. The county establishment is consisted of counties, autonomous counties, and cities at county level. In 2009, there are 31 provincial units, 333 prefecture-level units, and 2,858 county-level units in China. ${ }^{3}$ Table 2 shows the details.

\footnotetext{
2 The "cost function" of Frontier 4.1 which has the non-negative inefficiency effect option. Frontier 4.1 is a software developed by Coelli (1996).

3 Hong Kong, Macao and Taiwan are not included for statistical reasons.
} 
Table 2: Administrative Divisions in China (2009)

\begin{tabular}{|c|c|c|c|}
\hline At Provincial Level & Prefecture in the Sample & At Prefecture Level & At County Level \\
\hline Anhui & 17 & 17 & 105 \\
\hline Beijing & 0 & 0 & 18 \\
\hline Chongqing & 0 & 0 & 40 \\
\hline Fujian & 9 & 9 & 85 \\
\hline Gansu & 14 & 14 & 86 \\
\hline Guangdong & 20 & 21 & 121 \\
\hline Guangxi & 14 & 14 & 109 \\
\hline Guizhou & 9 & 9 & 88 \\
\hline Hainan & 18 & 2 & 20 \\
\hline Hebei & 11 & 11 & 172 \\
\hline Heilongjiang & 13 & 13 & 128 \\
\hline Henan & 18 & 17 & 159 \\
\hline Hubei & 16 & 13 & 103 \\
\hline Hunan & 14 & 14 & 122 \\
\hline Inner Mongolia & 11 & 12 & 101 \\
\hline Jiangsu & 13 & 13 & 106 \\
\hline Jiangxi & 8 & 11 & 99 \\
\hline Jilin & 9 & 9 & 60 \\
\hline Liaoning & 14 & 14 & 100 \\
\hline Ningxia & 4 & 5 & 22 \\
\hline Qinghai & 8 & 8 & 43 \\
\hline Shaanxi & 11 & 10 & 107 \\
\hline Shandong & 17 & 17 & 140 \\
\hline Shanghai & 0 & 0 & 18 \\
\hline Shanxi & 11 & 11 & 119 \\
\hline Sichuan & 21 & 21 & 181 \\
\hline Tianjin & 0 & 0 & 16 \\
\hline Xizang & 0 & 7 & 73 \\
\hline Xinjiang & 0 & 14 & 98 \\
\hline Yunnan & 16 & 16 & 129 \\
\hline Zhejiang & 11 & 11 & 90 \\
\hline National & 327 & 333 & 2,858 \\
\hline
\end{tabular}

Source: NSB (2010), p. 3.

The dataset has covered 303 prefectures from 1996 to 2009. As shown in Table 2, our sample covers 91 percent of prefectures in China in 2009. Beijing, Chongqing, Guizhou, Hubei, Shanghai, Tianjin, Xizang and Xinjiang are excluded from our study for various data and technical reasons. We have checked the consistency of each city throughout the study period. Our data sources are mainly drawn from the official 
data, including the provincial statistical yearbooks published by the National Bureau of Statistics of China.

\section{Methodological Issues}

Several major data-checking procedures need to be clarified. China carried out its first economic census in 2004. Data were adjusted to reflect the changes after 2004 at all levels. However, relevant adjustments before 2004 might not take place completely at prefecture level. Trends of the provincial data were used to match the corresponding necessary adjustment at the prefecture level if official data conversion was not made before 2004 .

During the 1990s, cities at various levels applied for upgrade to prefecture-level city (撤县建市), and largely intended to speed up urbanization. Such practice was stopped by the central government in the 2000s. Accordingly data for some prefectures changed dramatically from one year to another due to this interruption. If the totals of the provincial data are smooth over years during this period, we make no changes in the data during the early 2000s.

All outliers of the variables are removed by comparing the growth rates of the variables over time. For the missing values between two years, the average values will be filled in. For missing values with more than two years, the average growth rates will be used to derive the missing observations if the first and the last values are in the similar trends. In some cases, data are not available for irrigated land at prefecture level, approximation from the provincial data is adopted. Similarly, actual urbanization ratios are used if data of either urban or rural population are not available or reliable. 


\section{Variables}

Labour is the end-of-the-year number of workers participating in agriculture in which the farming, forestry, fishing, and animal husbandry are included. Output is measured by the gross value of farming, non-farming and industrial output which is deflated by CPI (1996 is the base year). Capital includes power generated by machineries measured by 10,000 kilowatts, while chemical fertilizers at net contents are considered as an intermediate input.

Three types of land are used in our analysis, namely, arable land, sown land, and irrigated land. While arable land is used to adjust heterogeneity of farmland in different prefectures, sown land of crops is directly used to produce farming output. Irrigated land is considered to be 25 percent more productive than land without irrigation (Tang, 1984, Wen 1993), that is

Land $=$ Sown Land $+0.25 \times \frac{\text { Irrigated Land }}{\text { Arable Land }} \times$ Sown Land

The level of urbanization is measured by the share of urban population to the total population, while the degree of industrialization is measured by the ratio of industrial output to total output at the prefecture level.

Table 3 shows the summary statistics of the major variables. The second column shows the units of measurement. The third and fourth columns show the mean and standard deviation. Both the farming output and non-farming agricultural output are deflated by provincial CPI deflator (with 1996 as the base year). 
Table 3: Summary Statistics

\begin{tabular}{lccc}
\hline \multicolumn{1}{c}{ Variable } & Unit & Mean & Standard Deviation \\
\hline Labour & million persons & 1.0676 & 0.9393 \\
Farming Output & 100 million Yuan & 50.90 & 45.01 \\
Non-farming Output & 100 million Yuan & 46.40 & 45.28 \\
Land & 1,000 hectares & 488.24 & 378.53 \\
Machineries & $10,000 \mathrm{kw}$ & 157.83 & 164.51 \\
Chemical Fertilizers & 10,000 tons & 18.73 & 54.83 \\
Urbanization & Ratio & 0.31 & 0.17 \\
Industrialization & Ratio & 0.77 & 0.92 \\
\hline
\end{tabular}

\section{Empirical Results}

\section{Labour-Use Model Estimates}

The labour requirement function of equation (7) was estimated using the maximumlikelihood method incorporated in the software Frontier 4.1. Both regional and provincial dummies were tried in order to capture the effect of geographical heterogeneity on agricultural labour requirement in rural China. ${ }^{4}$ The time trend and its quadratic term were included to gauge the effect of technological changes on labour use over time. Three models were estimated, namely, model 1 without an inefficiency specification, model 2 with provincial dummy variables in the labour use function only, and model 3 with provincial dummy variables in both the labour use function and the technical inefficiency specification (Table 4).

\footnotetext{
4 The models with regional dummy variables were excluded finally as they are not significant.
} 
Table 4: Estimates of Labour Requirement Function for Chinese Agriculture

\begin{tabular}{|c|c|c|c|c|c|c|}
\hline \multirow[t]{2}{*}{ Variable } & \multicolumn{2}{|c|}{ Model 1} & \multicolumn{2}{|c|}{ Model 2} & \multicolumn{2}{|c|}{ Model 3} \\
\hline & Coefficient & T-ratio & Coefficient & T-ratio & Coefficient & T-ratio \\
\hline \multicolumn{7}{|l|}{ Production } \\
\hline constant & -0.054 & -0.629 & 0.080 & 1.230 & -0.018 & 0.286 \\
\hline $\ln Y_{i t}^{a}$ & 0.209 & 10.308 & 0.145 & 10.284 & 0.134 & 7.427 \\
\hline $\ln Y_{i t}^{b}$ & 0.124 & 8.401 & 0.208 & 9.889 & 0.189 & 16.027 \\
\hline $\ln \mathrm{N}_{\mathrm{it}}$ & 0.403 & 23.117 & 0.286 & 16.154 & 0.285 & 17.337 \\
\hline $\ln \mathrm{M}_{\mathrm{it}}$ & 0.176 & 11.394 & 0.209 & 13.510 & 0.206 & 19.455 \\
\hline $\ln F_{i t}$ & 0.020 & 1.579 & 0.024 & 1.904 & 0.049 & 4.009 \\
\hline$t$ & 0.014 & 2.077 & -0.378 & -13.167 & 0.025 & 4.563 \\
\hline$t^{2}$ & -0.004 & -9.443 & 0.022 & 15.479 & -0.003 & -18.728 \\
\hline Provincial Dummy & Yes & & Yes & & Yes & \\
\hline \multicolumn{7}{|l|}{ Technical Inefficiency } \\
\hline constant & & & 0.402 & 3.366 & 0.716 & 6.189 \\
\hline Ind $_{i t}$ & - & & -0.007 & -3.345 & -0.028 & -46.346 \\
\hline $\mathrm{Urb}_{\mathrm{it}}$ & - & & -0.925 & -6.880 & -1.445 & -26.599 \\
\hline $\ln \mathrm{M}_{\mathrm{it}} / \ln \mathrm{N}_{\mathrm{it}}$ & - & & -0.012 & -16.880 & -0.014 & -7.111 \\
\hline$Y_{i t}^{a} / Y_{i t}$ & - & & 0.410 & 6.521 & 0.468 & 5.996 \\
\hline $\mathrm{T}$ & - & & 0.394 & 31.119 & -0.012 & -0.843 \\
\hline$t^{2}$ & - & & -0.026 & -31.800 & 0.000 & -1.286 \\
\hline Provincial Dummy & - & & No & & Yes & \\
\hline Log Likelihood & -1711.139 & & -1502.969 & & -1353.004 & \\
\hline
\end{tabular}


All estimated coefficients of outputs and inputs are statistically significant with the expected sign in three models. A relatively large value of its coefficient together with a high student- $t$ value, the farming land variable is considered to be the most important in the three models. This is consistent with observations in most underdeveloped economies.

To examine the effect of technological progress on the observed labour for agricultural production, the following partial derivative is calculated:

$\frac{\partial \ln L_{t}}{\partial t}=\alpha_{6}+2 t \alpha_{7}$

The estimated mean value is -2.758 for model 3 , which means that technological change on average has a negative impact on labour requirement in Chinese agriculture (that is a reducing effect). It is shown that the effect was negative for all the years but 1995, 1996 and 1997.

Regarding the inefficiency estimates, the coefficients of the industrialization and urbanization variables are statistically significant at 5 percent level with the expected sign in models 2 and 3 while those of the mechanization and farming output ratio variables are statistically significant but with the unexpected sign. Overall, in order to find out the most suitable model, we check the LR test of the one-side error among the three models (Table 5). The test follows the mixed $\chi^{2}$ distribution proposed by Kodde and Palm (1986):

Table 5: Tests for Model Specification

\begin{tabular}{lcc}
\hline Null Hypothesis & Test Statistics & 5\% Critical Values \\
\hline (A) $H_{0}: \beta_{1}=\beta_{2}=\cdots=\beta_{6}=0$ & 416.339 & 11.911 \\
(B) $H_{0}: \beta_{1}=\beta_{2}=\cdots=\delta_{6}=\theta_{1} \ldots=\theta_{24}=0$ & 716.269 & 43.194 \\
(C) $H_{0}: \theta_{1}=\cdots=\theta_{24}=0$ & 299.930 & 35.827 \\
\hline
\end{tabular}

(A): Model 1 vs. Model 2; (B) Model 3 vs. Model 1; (C) Model 3 vs. Model 2. 
The first test compares model 2 with model 1 . The null hypothesis is that the estimated coefficients of all environmental variables are simultaneously equal to zero, and thus the inefficiency specification is invalid (i.e., OLS is preferred). The test statistic shows that the null hypothesis is rejected at 5 percent significance level. The second test compares model 3 with model 1 . The null hypothesis is that the estimated coefficients of all environmental variables and provincial dummy variables in the technical inefficiency function are all equal to zero. This hypothesis is again rejected at a high level of significance. The third test compares model 3 with model 2. The null hypothesis is that the estimated coefficients of the provincial dummy variables in the inefficiency specification are all equal to zero. The hypothesis is also rejected. The results imply that the provincial dummy variables are significantly important to explain the regional heterogeneity of labour inefficiency in model 3. Model 3 is thus accepted as the preferred model.

\section{Measured Surplus Labour in Chinese Agriculture}

The estimated technical inefficiency scores at prefecture level are first averaged into provincial inefficiency level. The amount of surplus labour at provincial level is then calculated using equation (6), and the estimated figures are further combined into either regional or national across years. The size of surplus labour and its ratio over observed labour are reported in Tables 6 and 7.

The estimated national surplus labour ranges from 119 million in 1995 to 55 million in 2009, with the surplus labour ratio decreasing from 36.5 percent of the agricultural labour in 1995 to 21.4 percent in 2009. The provinces in eastern China had the largest size of surplus labour throughout the sample period while the central region had the smallest surplus labour ratio. 
Table 6: Estimated National Surplus Agricultural Labour and Its Ratios, 1995-2009

\begin{tabular}{cccc}
\hline Year & Agriculture Labour & Surplus Labour & Surplus Labour Ratio \\
\hline 1995 & 326.4 & 119.1 & 0.37 \\
1996 & 316.6 & 107.0 & 0.34 \\
1997 & 318.7 & 107.1 & 0.34 \\
1998 & 318.9 & 111.6 & 0.35 \\
1999 & 314.8 & 106.7 & 0.34 \\
2000 & 320.4 & 96.1 & 0.30 \\
2001 & 321.8 & 93.0 & 0.29 \\
2002 & 317.9 & 86.1 & 0.27 \\
2003 & 312.1 & 81.6 & 0.26 \\
2004 & 307.7 & 76.0 & 0.25 \\
2005 & 297.3 & 69.6 & 0.23 \\
2006 & 286.3 & 63.6 & 0.22 \\
2007 & 276.9 & 65.9 & 0.24 \\
2008 & 268.7 & 63.2 & 0.24 \\
2009 & 258.8 & 55.4 & 0.22 \\
\hline
\end{tabular}

Labour is in million persons.

Table 7: Regional Surplus Labour and Surplus Ratios

\begin{tabular}{lccl}
\hline Region & Surplus Labour & Surplus Labour Ratio & \multicolumn{1}{c}{ Provinces } \\
\hline East & 37.2 & 0.27 & $\begin{array}{l}\text { Fujian, Guangdong, Hainan, Hebei, Jiangsu, } \\
\text { Liaoning, Shandong, Zhejiang } \\
\text { Central }\end{array}$ \\
West & 20.5 & 0.19 & $\begin{array}{l}\text { Anhui, Heilongjiang, Henan, Hubei, Hunan, } \\
\text { Jiangxi, Jilin, Shanxi, } \\
\text { Gansu, Guangxi, Guizhou, Inner Mongolia, } \\
\text { Ningxia, Qinghai, Sichuan, Shaanxi, Yunnan }\end{array}$ \\
\hline
\end{tabular}

The figures indicate the average regional surplus from 1995 to 2009. Labour is in million persons.

Our results show that the estimated surplus agricultural labour in rural China has been decreasing since 2001 after China joined WTO. This is different from our previous estimates. The size of surplus dropped significantly since 2004, from 76 million to 55 million in 2009. If our estimates could reflect the labour reality in rural 
China during this period, there may be important policy implications. To understand our results, several points are summarized here.

First, our estimates are based on prefecture-level data which are considered to be more reliable and consistent with SFA requirements than using provincial or national data in other studies. Accordingly, our results might be more precise than the previous estimates.

Second, a comparison of the results of Kwan (2009), Bhattacharyya \& Parker (1999) and Guo (2007) with ours shows that the estimated surplus labour figures are very close to each other until 2000, indicating that the method used in this paper is trustworthy and comparable with other studies.

Table 8: Comparison of Estimated Surplus Labour by Various Studies

\begin{tabular}{lcccccc}
\hline Author & Period & 1990 & 1995 & 2000 & 2005 & 2009 \\
\hline $\begin{array}{l}\text { Bhattacharyya \& } \\
\text { Parker(1999) }\end{array}$ & $1980-1995$ & 127.0 & 119.3 & - & - & - \\
Guo (2005) & & & & & & \\
Kwan (2009) & $1996-2005$ & - & $98.3 *$ & 101.7 & 94.0 & - \\
This Study & $1980-2007$ & 137.8 & 116.3 & 122.6 & 137.4 & - \\
\hline
\end{tabular}

Figures are in million persons. ${ }^{*} 1996$ figure.

Third, our results indicate that the observed agricultural labour has decreased more rapidly from 2005 to 2009, from around 297 million to 259 million, which implies a reduction of 39 million. Correspondingly, the decrease of labour was only 29 million during the period from 1995 to 2005, from around 326 million to 297 million. Together with the improvement of labour efficiency, the absolute size of surplus labour has dropped significantly, around 14 million during the period of 2005-2009.

Fourth, our estimated inefficiency levels are relatively lower than the other estimates, especially after 2002 . We believe that the agricultural labour efficiency has 
improved generally during this period. In general, China had more agricultural surplus labour in the 1980s and 1990s. Our data cover the period from the mid-1990s to the end of 2000s, which is much later than (but probably shorter than) those covered by some other studies. Accordingly, the frontier estimates of inefficiency are affected more by the later years in our study. We suspect that if prefecture level data in the 1980s and early 1990s could be found, our overall estimated size of surplus labour may be slightly larger.

Fifth, the decrease of surplus labour is likely influenced by the increase of minimum wage in recent years, which might attract more redundant agricultural labour to be employed in urban China. The minimum wage regulations were introduced in $1993,{ }^{5}$ following the principle under the "minimum wage treaty" of the International Labour Organization (ILO) (Wang \& Gunderson, 2010). Yet, the minimum wages were substantially adjusted upwards under the new regulations in 2004. ${ }^{6}$ Table 9 shows the regional trends of the minimum wages from 2000 to 2010. It is found that the national average of nominal minimum wages had increased from around RMB300 to more than RMB800 during this period. The pace of growth was slightly higher in the second half than that in the first half of the 2000s. However, the minimum wage increases in the central and the west regions were higher in the second period, implying that more workers might be absorbed by the nonagricultural production through the protection of minimum wage policy.

Table 9: Nominal Minimum Wages in China, 2000-2010 (Selected Years)

\begin{tabular}{lcccccccc}
\hline & 2000 & 2002 & 2004 & 2005 & 2006 & 2008 & 2010 \\
\hline East & 358 & 422 & 545 & 591 & 668 & 781 & 958 \\
Central & 291 & 331 & 421 & 444 & 513 & 622 & 818 \\
West & 246 & 333 & 397 & 417 & 533 & 644 & 759 \\
\hline National & 299 & 365 & 458 & 488 & 577 & 688 & 848 \\
\hline
\end{tabular}

Data are compiled from the Zhongguo Laodongwang (http://www.labournet.com.cn). The figures are average nominal minimum monthly wages.

5 The "Qiye Zuidi Gongzi Guiding” (Provision of Minimum Wage of Enterprises) issued by the Ministry of Labour, December 1993.

6 The Order 21 issued by the Ministry of Labour and Social Security in 2004. 


\section{Surplus Agricultural Labour and China's Dual Economy}

The study of surplus labour in rural China has partly its origin of the debate whether China has already passed the turning point of the dualistic economic framework which was originally proposed by Lewis (1954). The policy implication of such turning point lies on the fundamental change of the nature and mechanism of the labour market of China: firms will expect to compete for labour in both of the countryside and cities. In the long run, labour is potentially reducing its role as a driving factor input in determining output growth in China.

There are basically two approaches to examine the turning point issue. The first is to compare the income and the marginal productivity of rural workforce at subsistence level, and the second is to estimate the size of the so-called surplus labour in the traditional sector. With the first approach, the Lewis turning point could be confirmed if the gap between the estimated marginal product of labour and the wages is convergent and eventually equal to each other. With the second approach, most of peasants are considered working with very low marginal productivity and surviving with subsistence wages if the estimated amount of surplus labour is significantly and relatively large in the traditional sector (mainly the agriculture). Theoretically, these two approaches are expected to generate consistent results.

In the case of China, there are various practical concerns of applying the above two approaches to study the turning point issue. For the first approach of comparing income and marginal productivity, peasant income sources may not be appropriately reported and thus the gap between these two variables could be mistakenly calculated even though a proper production function is specified and estimated to figure out the marginal product of labour in the traditional sector. For the second 
approach of deriving surplus labour, the estimated surplus size may be varying if different methods are adopted.

This paper examines the turning point issue with the second approach. There are several theoretical and empirical concerns of this approach applying to China. Theoretically, economists still question the existence of zero marginal product of labour. Amongst, Ge \& Yang (2011) distinguishes the $M P_{L}$ in agriculture between the classical and neoclassical treatments. In respond to many disagreements, Lewis himself explained this through an example of market stalls, arguing that "they are crowded with people who are not as fully occupied as they would wish to be, and therefore if a certain percentage of them were removed, the amount traded would be the same, since those remained would do more trade" (Lewis, 1972). In fact, "whether marginal productivity is zero or negligible is not at the core of fundamental importance to our analysis. It was probably a mistake to mention marginal productivity at all, since this has merely led to an irrelevant and intemperate controversy" (Lewis, 1954).

It is our opinion that the assumption of surplus labour with negligible marginal labour productivity due to huge population facing limited supply of land for production in developing economies is basically for analytical simplicity: suggesting that the pool of these labourers could be transferred to non-agricultural production without reducing agricultural output. Due to the existence of this group of surplus labourers, producers in the modern sectors face the "unlimited supply of labour" for their production.

Empirically, there are no precise methods of deriving the size of surplus labour. Kwan (2009) summarized major economic and non-economic techniques and found that the estimated figures could be very different. We adopt the production efficiency approach to estimate the required labour and subtracted it from the 
reported agricultural labour to obtain the surplus labour. There are a number of reasons. First of all, the estimated frontier could be treated as the best hypothetical labour required for producing output with a given level of technology, and this condition satisfies the requirement of the Lewis turning point where wages equal to the marginal product of labour. Second, the difference between the observed labour utilized for production and the estimated labour requirement is regarded as the amount of surplus labour, which is expected to follow the path of labour utilization with $M P_{L}$ between zero and $M P_{L}=w$ under the original Lewis model. In other words, the quantity of surplus labour in our approach in theory could include all those with marginal productivity below $M P_{L}=w$.

Finally, the reliability of agricultural labour data is a major constraint of our analysis. According to the National Bureau of Statistics, agricultural labour is defined as those who spend at least 50 percent of their time in agriculture. However, the figures provide no information about whether the individual labourers include those with local hukou or not, and how much time they spend for various rural activities. In addition, measurement biases due to peasants' choice between work and leisure might further affect the number of effective agricultural labour. More importantly, agricultural labour figures from the recent two agricultural censuses are very different from those official data (Wang, 2010). Consequently, we are not sure if the official data under-report or over-report the individuals who engaged in agriculture since peasants have more employment opportunities after economic reform.

\section{Conclusions}

This article attempts to quantify the surplus agricultural labour in China's countryside at prefecture level between 1996 and 2009 when China was experiencing both economic reform and greater integration with the global economy. An input / 
labour requirement function in Cobb-Douglas form with stochastic frontier framework was estimated to derive the required labour use in agriculture. The amount of surplus agricultural labour is calculated by deducting the required labour from the observed labour. Our estimated surplus is comparable to Kwan (2009) and Bhattacharyya \& Parker (1999) and Guo (2007). Our findings are consistent with Knight et al (2011) who approached the same issue with data from the China Household Income Project (2002 and 2007), and Golley \& Meng (2011) who drew various conclusions based on the Rural-Urban Migration in China and Indonesia Project in 2008 and 2011.

Several authors argued that the wage of unskilled labour in urban China has been increasing (Wang 2010, Zhang et al. 2011), on the one hand. On the other hand, Cai (2010) and Wang et al. (2011) presented evidence of labour shortage. All these studies support the argument that the labour markets in China are not fully developed and hence surplus labour and shortage of workers coexist. We reckon that the recent observation about labour shortage is likely to be regional and sectoral, partly due to the nature of dualism and partly the smooth demographic transition in rural China. Marginal product of labour has been rising over the years, together with the real wage increase in selected sectors and in coastal provinces. Our estimated sizable national and regional surplus agricultural labour implies that China is probably moving into the second stage of the Lewsi-Fei-Ranis dual economy structure. That is, the marginal productivity of surplus labour is increasing and probably higher than the average product of labour, but has not yet reached the market wage. In other words, China's labour market has not fully commercialized.

If our estimates match the current labour market development in rural China, there are several policy implications. First of all, China is still facing huge pressure of inefficient labour use in its countryside. However, the absolute size of surplus seems to decrease in the last few years. Second, the continuous decline of surplus 
agricultural labour lends support to the argument that China is approaching the Lewis turning point. However, real wages and marginal labour productivity should be examined before making such claim. Third, our results appear to be consistent with the current debate on the wage increase and the labour shortage in some sectors and regions.

\section{References}

Aigner, D., C. Lovell \& P. Schmidt (1977). “Formulation and Estimation of Stochastic Frontier Production Function Models" Journal of Econometrics, 6: 21-37.

Ba, Shusong (2011) "Zhongguo Jingji yi qiaoren yueguo liuyishi guaidian" in Jingji Cankao (Economic Information), May $5^{\text {th }}$.

Battese, G. \& T. Coelli (1995). “A Model for Technical Inefficiency Effects in a Stochastic Frontier Production Function for Panel Data" Empirical Economics, 20: 325-32.

Battese, G., A. Heshmati \& L. Hjalmarsson (2000). “Efficiency of Labour Use in Swedish Banking Industry: A Stochastic Frontier Approach" Empirical Economics, 25: $623-640$.

Bhattacharyya, A. \& Parker, E. (1999). “Labor Productivity and Migration in Chinese Agriculture A Stochastic Frontier Approach" China Economic Review, 10: 59-74.

Cai, Fang. (2007) “Nongcun Shengyu Laodongli de Renkoxue Fenxi” in Cai, Fang (ed.) Zhongguo Renkou yu Laodong Wenti Baogou No. 8 (Reports on China's Population and Labour No. 8). Beijing: Shehui Wenxian Chubanshe, pp. 95-112.

Coelli, T. (1996) “A Guide to FRONTIER 4.1: A Computer Program for Stochastic Frontier Production and Cost Function Estimation" Centre for Efficiency and Productivity Analysis, University of New England, CEPA Working Paper 96/07.

Coelli, T., P. Rao, C. O’Donnell, \& G. Battese (2005). An Introduction to Efficiency and Productivity Analysis, $2^{\text {nd }}$ ed. New York: Springer. 
Diewert, W. E. (1974). “Functional Forms for Revenue and Factor Requirements Functions" International Economic Review, 15(1): 119-130.

Cai, F. (2010). “Demographic Transition, Demographic Dividend, and Lewis Turning Point in China" China Economic Journal, 3(2): 107-119.

Ge, S. \& D. Yang (2011). “Labor Market Developments in China: A Neoclassical View” China Economic Review, 22(4): 611-625.

Golley, J. \& X. Meng (2011). “Has China Run Out of Surplus Labour?” China Economic Review, 22(4): 555-572.

Greene, W. (2004). “Distinguishing Between Heterogeneity and Inefficiency: Stochastic Frontier Analysis of the World Health Organization's Panel Data on National Health Care Systems" Health Economics, 13: 959-980.

Greene, W. (2005). "Reconsidering Heterogeneity in Panel Data Estimators of the Stochastic Frontier Model" Journal of Econometrics, 126: 269-303.

Guo, J. X. (2007)."The Estimation of Surplus Labor in Chinese Agriculture in 19962005: A Stochastic Frontier Approach" Nankai Economic Studies, 4: 72-81 (in Chinese).

Kodde, D. \& F. Palm. (1986). "Wald Criteria for Jointly Testing Equality and Inequality Restrictions" Econometrica, 54(5): 1243-1248.

Kumbhakar, S. \& L. Hjalmarsson (1995). “Labour-Use Efficiency in Swedish Social Insurance Offices" Journal of Applied Econometrics, 10(1): 33-47.

Knight, J., Q. Deng \& S. Li (2011). “The Puzzle of Migrant Labour Shortage and Rural Labour Surplus in China" China Economic Review, 22(4): 585-600.

Kwan, F. (2009). "Agricultural Labour and the Incidence of Surplus Labour: Experience from China during Reform" Journal of Chinese Economic and Business Studies, 7(3): 341-361.

Lewis, W. A. (1954). "Economic Development With Unlimited Supplies of Labour" Manchester School of Economic and Social Studies, 22: 139-191. 
Lewis, W. A. (1972). "Reflections on Unlimited Labour" in L.E.D. Marco, ed. International Economics and Development. Essays in Honor of Raoul Prebisch. New York: Academic Press: 75-96.

Minami, R. \& X. Ma (2010). “The Lewis Turning Point of Chinese Economy: Comparison with Japanese Experience" China Economic Journal 3(2): 163-179.

National Bureau of Statistics of China (2010). Zhongguo Tongji Nianjian 2010 [China Statistical Yearbook 2010]. Beijing: China Statistics Press.

Tang, A.M. (1984). An Analytical and Empirical Investigation of Agriculture in Mainland China, 1952 - 1980. Taipei: Chung-hua Institution for Economic Research.

Wang, J. \& M. Gunderson (2010). “Minimum Wage Impacts in China: Estimates from a Prespecified Research Design, 2000-2007" Contemporary Economic Policy, 29(3): 392-406.

Wang, M. (2010). “The Rise of Labor Cost and the Fall of Labor Input: Has China Reached Lewis Turning Point?" China Economic Journal, 3(2): 137-153.

Wang, X., J. Huang, L. Zhang \& S. Rozelle (2011). “The Rise of Migration and the Fall of Self Employment in Rural China's Labor Market" China Economic Review, 22(4): 573-584.

Wen, J.G. (1993). “Total Factor Productivity Change in China's Farming Sector: 1952 - 1989" Economic Development and Cultural Change, 42(1):1-42.

Zhang, X., J. Yang \& S. Wang (2011). “China Has Reached the Lewis Turning Point” China Economic Review, 22(4): 524-554. 
Editor, UWA Economics Discussion Papers:

Ernst Juerg Weber

Business School - Economics

University of Western Australia

35 Sterling Hwy

Crawley WA 6009

Australia

Email: ecoadmin@biz.uwa.edu.au

The Economics Discussion Papers are available at:

1980 - 2002: http://ecompapers.biz.uwa.edu.au/paper/PDF\%20of\%20Discussion\%20Papers/

Since 2001: http://ideas.repec.org/s/uwa/wpaper1.html

Since 2004: http://www.business.uwa.edu.au/school/disciplines/economics

\begin{tabular}{|c|c|c|}
\hline \multicolumn{3}{|c|}{$\begin{array}{l}\text { ECONOMICS DISCUSSION PAPERS } \\
2011\end{array}$} \\
\hline $\begin{array}{l}\text { DP } \\
\text { NUMBER }\end{array}$ & AUTHORS & TITLE \\
\hline 11.01 & Robertson, P.E. & $\begin{array}{l}\text { DEEP IMPACT: CHINA AND THE WORLD } \\
\text { ECONOMY }\end{array}$ \\
\hline 11.02 & Kang, C. and Lee, S.H. & $\begin{array}{l}\text { BEING KNOWLEDGEABLE OR SOCIABLE? } \\
\text { DIFFERENCES IN RELATIVE IMPORTANCE OF } \\
\text { COGNITIVE AND NON-COGNITIVE SKILLS }\end{array}$ \\
\hline 11.03 & Turkington, D. & DIFFERENT CONCEPTS OF MATRIX CALCULUS \\
\hline 11.04 & Golley, J. and Tyers, R. & $\begin{array}{l}\text { CONTRASTING GIANTS: DEMOGRAPHIC CHANGE } \\
\text { AND ECONOMIC PERFORMANCE IN CHINA AND } \\
\text { INDIA }\end{array}$ \\
\hline 11.05 & Collins, J., Baer, B. and Weber, E.J. & $\begin{array}{l}\text { ECONOMIC GROWTH AND EVOLUTION: } \\
\text { PARENTAL PREFERENCE FOR QUALITY AND } \\
\text { QUANTITY OF OFFSPRING }\end{array}$ \\
\hline 11.06 & Turkington, D. & $\begin{array}{l}\text { ON THE DIFFERENTIATION OF THE LOG } \\
\text { LIKELIHOOD FUNCTION USING MATRIX } \\
\text { CALCULUS }\end{array}$ \\
\hline 11.07 & Groenewold, N. and Paterson, J.E.H. & $\begin{array}{l}\text { STOCK PRICES AND EXCHANGE RATES IN } \\
\text { AUSTRALIA: ARE COMMODITY PRICES THE } \\
\text { MISSING LINK? }\end{array}$ \\
\hline 11.08 & Chen, A. and Groenewold, N. & $\begin{array}{l}\text { REDUCING REGIONAL DISPARITIES IN CHINA: IS } \\
\text { INVESTMENT ALLOCATION POLICY EFFECTIVE? }\end{array}$ \\
\hline 11.09 & Williams, A., Birch, E. and Hancock, P. & $\begin{array}{l}\text { THE IMPACT OF ON-LINE LECTURE RECORDINGS } \\
\text { ON STUDENT PERFORMANCE }\end{array}$ \\
\hline 11.10 & Pawley, J. and Weber, E.J. & $\begin{array}{l}\text { INVESTMENT AND TECHNICAL PROGRESS IN THE } \\
\text { G7 COUNTRIES AND AUSTRALIA }\end{array}$ \\
\hline 11.11 & Tyers, R. & $\begin{array}{l}\text { AN ELEMENTAL MACROECONOMIC MODEL FOR } \\
\text { APPLIED ANALYSIS AT UNDERGRADUATE LEVEL }\end{array}$ \\
\hline 11.12 & Clements, K.W. and Gao, G. & QUALITY, QUANTITY, SPENDING AND PRICES \\
\hline
\end{tabular}




\begin{tabular}{|c|c|c|}
\hline 11.13 & Tyers, R. and Zhang, Y. & $\begin{array}{l}\text { JAPAN'S ECONOMIC RECOVERY: INSIGHTS FROM } \\
\text { MULTI-REGION DYNAMICS }\end{array}$ \\
\hline 11.14 & McLure, M. & A. C. PIGOU'S REJECTION OF PARETO'S LAW \\
\hline 11.15 & Kristoffersen, I. & $\begin{array}{l}\text { THE SUBJECTIVE WELLBEING SCALE: HOW } \\
\text { REASONABLE IS THE CARDINALITY } \\
\text { ASSUMPTION? }\end{array}$ \\
\hline 11.16 & Clements, K.W., Izan, H.Y. and Lan, Y. & VOLATILITY AND STOCK PRICE INDEXES \\
\hline 11.17 & Parkinson, M. & $\begin{array}{l}\text { SHANN MEMORIAL LECTURE 2011: SUSTAINABLE } \\
\text { WELLBEING - AN ECONOMIC FUTURE FOR } \\
\text { AUSTRALIA }\end{array}$ \\
\hline 11.18 & Chen, A. and Groenewold, N. & $\begin{array}{l}\text { THE NATIONAL AND REGIONAL EFFECTS OF } \\
\text { FISCAL DECENTRALISATION IN CHINA }\end{array}$ \\
\hline 11.19 & Tyers, R. and Corbett, J. & $\begin{array}{l}\text { JAPAN'S ECONOMIC SLOWDOWN AND ITS } \\
\text { GLOBAL IMPLICATIONS: A REVIEW OF THE } \\
\text { ECONOMIC MODELLING }\end{array}$ \\
\hline 11.20 & Wu, Y. & $\begin{array}{l}\text { GAS MARKET INTEGRATION: GLOBAL TRENDS } \\
\text { AND IMPLICATIONS FOR THE EAS REGION }\end{array}$ \\
\hline 11.21 & Fu, D., Wu, Y. and Tang, Y. & $\begin{array}{l}\text { DOES INNOVATION MATTER FOR CHINESE HIGH- } \\
\text { TECH EXPORTS? A FIRM-LEVEL ANALYSIS }\end{array}$ \\
\hline 11.22 & Fu, D. and Wu, Y. & $\begin{array}{l}\text { EXPORT WAGE PREMIUM IN CHINA'S } \\
\text { MANUFACTURING SECTOR: A FIRM LEVEL } \\
\text { ANALYSIS }\end{array}$ \\
\hline 11.23 & Li, B. and Zhang, J. & $\begin{array}{l}\text { SUBSIDIES IN AN ECONOMY WITH ENDOGENOUS } \\
\text { CYCLES OVER NEOCLASSICAL INVESTMENT AND } \\
\text { NEO-SCHUMPETERIAN INNOVATION REGIMES }\end{array}$ \\
\hline 11.24 & Krey, B., Widmer, P.K. and Zweifel, P. & $\begin{array}{l}\text { EFFICIENT PROVISION OF ELECTRICITY FOR THE } \\
\text { UNITED STATES AND SWITZERLAND }\end{array}$ \\
\hline 11.25 & Wu, Y. & $\begin{array}{l}\text { ENERGY INTENSITY AND ITS DETERMINANTS IN } \\
\text { CHINA'S REGIONAL ECONOMIES }\end{array}$ \\
\hline
\end{tabular}




\begin{tabular}{|c|c|c|}
\hline \multicolumn{3}{|c|}{$\begin{array}{l}\text { ECONOMICS DISCUSSION PAPERS } \\
2012\end{array}$} \\
\hline $\begin{array}{l}\text { DP } \\
\text { NUMBER }\end{array}$ & AUTHORS & TITLE \\
\hline 12.01 & $\begin{array}{l}\text { Clements, K.W., Gao, G., and } \\
\text { Simpson, T. }\end{array}$ & $\begin{array}{l}\text { DISPARITIES IN INCOMES AND PRICES } \\
\text { INTERNATIONALLY }\end{array}$ \\
\hline 12.02 & Tyers, R. & $\begin{array}{l}\text { THE RISE AND ROBUSTNESS OF ECONOMIC FREEDOM } \\
\text { IN CHINA }\end{array}$ \\
\hline 12.03 & Golley, J. and Tyers, R. & $\begin{array}{l}\text { DEMOGRAPHIC DIVIDENDS, DEPENDENCIES AND } \\
\text { ECONOMIC GROWTH IN CHINA AND INDIA }\end{array}$ \\
\hline 12.04 & Tyers, R. & LOOKING INWARD FOR GROWTH \\
\hline 12.05 & Knight, K. and McLure, M. & THE ELUSIVE ARTHUR PIGOU \\
\hline 12.06 & McLure, M. & $\begin{array}{l}\text { ONE HUNDRED YEARS FROM TODAY: A. C. PIGOU'S } \\
\text { WEALTH AND WELFARE }\end{array}$ \\
\hline 12.07 & Khuu, A. and Weber, E.J. & HOW AUSTRALIAN FARMERS DEAL WITH RISK \\
\hline 12.08 & Chen, M. and Clements, K.W. & PATTERNS IN WORLD METALS PRICES \\
\hline 12.09 & Clements, K.W. & UWA ECONOMICS HONOURS \\
\hline 12.10 & Golley, J. and Tyers, R. & $\begin{array}{l}\text { CHINA'S GENDER IMBALANCE AND ITS ECONOMIC } \\
\text { PERFORMANCE }\end{array}$ \\
\hline 12.11 & Weber, E.J. & $\begin{array}{l}\text { AUSTRALIAN FISCAL POLICY IN THE AFTERMATH OF } \\
\text { THE GLOBAL FINANCIAL CRISIS }\end{array}$ \\
\hline 12.12 & Hartley, P.R. and Medlock III, K.B. & $\begin{array}{l}\text { CHANGES IN THE OPERATIONAL EFFICIENCY OF } \\
\text { NATIONAL OIL COMPANIES }\end{array}$ \\
\hline 12.13 & Li, L. & $\begin{array}{l}\text { HOW MUCH ARE RESOURCE PROJECTS WORTH? A } \\
\text { CAPITAL MARKET PERSPECTIVE }\end{array}$ \\
\hline 12.14 & Chen, A. and Groenewold, N. & $\begin{array}{l}\text { THE REGIONAL ECONOMIC EFFECTS OF A } \\
\text { REDUCTION IN CARBON EMISSIONS AND AN } \\
\text { EVALUATION OF OFFSETTING POLICIES IN CHINA }\end{array}$ \\
\hline 12.15 & Collins, J., Baer, B. and Weber, E.J. & $\begin{array}{l}\text { SEXUAL SELECTION, CONSPICUOUS CONSUMPTION } \\
\text { AND ECONOMIC GROWTH }\end{array}$ \\
\hline 12.16 & Wu, Y. & TRENDS AND PROSPECTS IN CHINA'S R\&D SECTOR \\
\hline 12.17 & Cheong, T.S. and Wu, Y. & $\begin{array}{l}\text { INTRA-PROVINCIAL INEQUALITY IN CHINA: AN } \\
\text { ANALYSIS OF COUNTY-LEVEL DATA }\end{array}$ \\
\hline 12.18 & Cheong, T.S. & THE PATTERNS OF REGIONAL INEQUALITY IN CHINA \\
\hline 12.19 & Wu, Y. & $\begin{array}{l}\text { ELECTRICITY MARKET INTEGRATION: GLOBAL } \\
\text { TRENDS AND IMPLICATIONS FOR THE EAS REGION }\end{array}$ \\
\hline 12.20 & Knight, K. & $\begin{array}{l}\text { EXEGESIS OF DIGITAL TEXT FROM THE HISTORY OF } \\
\text { ECONOMIC THOUGHT: A COMPARATIVE } \\
\text { EXPLORATORY TEST }\end{array}$ \\
\hline 12.21 & Chatterjee, I. & $\begin{array}{l}\text { COSTLY REPORTING, EX-POST MONITORING, AND } \\
\text { COMMERCIAL PIRACY: A GAME THEORETIC } \\
\text { ANALYSIS }\end{array}$ \\
\hline 12.22 & Pen, S.E. & QUALITY-CONSTANT ILLICIT DRUG PRICES \\
\hline 12.23 & Cheong, T.S. and Wu, Y. & $\begin{array}{l}\text { REGIONAL DISPARITY, TRANSITIONAL DYNAMICS } \\
\text { AND CONVERGENCE IN CHINA }\end{array}$ \\
\hline
\end{tabular}




\begin{tabular}{|l|l|l|}
\hline 12.24 & Ezzati, P. & $\begin{array}{l}\text { FINANCIAL MARKETS INTEGRATION OF IRAN WITHIN } \\
\text { THE MIDDLE EAST AND WITH THE REST OF THE } \\
\text { WORLD }\end{array}$ \\
\hline 12.25 & Kwan, F., Wu, Y. and Zhuo, S. & $\begin{array}{l}\text { RE-EXAMINATION OF THE SURPLUS AGRICULTURAL } \\
\text { LABOUR IN CHINA }\end{array}$ \\
\hline 12.26 & Wu. Y. & \begin{tabular}{l} 
R\&D BEHAVIOUR IN CHINESE FIRMS \\
\hline 12.27
\end{tabular} \\
\hline Tang, S.H.K. and Yung, L.C.W. & $\begin{array}{l}\text { MAIDS OR MENTORS? THE EFFECTS OF LIVE-IN } \\
\text { FOREIGN DOMESTIC WORKERS ON SCHOOL } \\
\text { CHILDREN'S EDUCATIONAL ACHIEVEMENT IN HONG } \\
\text { KONG }\end{array}$ \\
\hline 12.28 & Groenewold, N. & $\begin{array}{l}\text { AUSTRALIA AND THE GFC: SAVED BY ASTUTE } \\
\text { FISCAL POLICY? }\end{array}$ \\
\hline
\end{tabular}

\begin{tabular}{|l|l|l|}
\hline \multicolumn{2}{|c|}{ ECONOMICS DISCUSSION PAPERS } \\
\multicolumn{2}{|c|}{2013} \\
\hline $\begin{array}{l}\text { DP } \\
\text { NUMBER }\end{array}$ & AUTHORS & TITLE \\
\hline 13.01 & $\begin{array}{l}\text { Chen, M., Clements, K.W. and } \\
\text { Gao, G. }\end{array}$ & THREE FACTS ABOUT WORLD METAL PRICES \\
\hline 13.02 & Collins, J. and Richards, O. & $\begin{array}{l}\text { EVOLUTION, FERTILITY AND THE AGEING } \\
\text { POPULATION }\end{array}$ \\
\hline & & \\
\hline & & \\
\hline & & \\
\hline & &
\end{tabular}

